\title{
Fluid Futures
}

\section{NIKOLE BOUCHARD}

University of Wisconsin-Milwaukee
According to NASA Scientists, the most recent climate change data suggests that sea levels will rise 3' or more within the next 100-200 years. Shanghai, China's largest city, is home to 24 million people. Climate Central estimates show that $76 \%$ of Shanghai's populated territory will be swallowed by rising seas if the earth warms by $4^{\circ} \mathrm{C}$ in the next 95 years. At the same time, "today more than a third of the world's population-about $\mathbf{2 . 7}$ billion people-live in river basins that experience severe water scarcity for at least one month each year." ${ }^{1}$ Global freshwater demand "is expected to exceed current supply by more than 40 percent by the year 2030," 2 at which point nearly half of the world's population will be living in high water stress regions. Rethinking the ways in which we live with and without (clean) water is essential to ensure a more feasible future. Fluid Futures presents three water related setbacks and resilient design responses that span various scales-small, medium and large-and citiesNew York, Suzhou and Sendai.

\section{SMALL SCALE: WORKING WITH WET + WILD! URBAN WASTE TO CREATE WONDER}

In 2008, for the first time in history, more than half of the world's population was concentrated in urban centers. "Population in urban areas is projected to increase from 3.6 billion in 2011 to 6.3 billion in 2050."3 Megacities, defined as cities with more than 10 million people, are on the rise. "In 1970, the world had two Megacities-Tokyo and New York City-but today there are 23." ${ }^{4}$ Metropolises like New York City are bursting at the seams with an average of 10,000 to 30,000 people per square mile. As a result, our cities are producing alarming amounts of waste water, a sickening surplus of sludge and absurd extents of food scraps. The effects of population pressures, compounded with environmental issues regarding ground water quality, natural disasters, escalating energy costs and soaring food prices would suggest the urgent need to consider more efficient and productive forms of urbanism. To do this, re-conceptualizing our approach to urban waste is essential. Megacities around the world from Mexico City, to Rio de Janeiro, to New York City are working hard to put plans in place that conserve forests and wetlands and improve water management practices. A closer look at New York City's current and future urban agendas reveals exciting opportunities for resilient design.

In October of 2012, Hurricane Sandy struck New York City, devastating the entire tri-state area. This natural disaster "highlighted regional and international vulnerabilities, the demand to act, and the need to anticipate future scenarios." 5 In the wake of the storm, New York City was left with approximately 8,000 toppled street trees, more than 650,000 damaged homes and a severely broken transportation infrastructure. Nearly 300 Staten Island homeowners sold their doomed properties to the state in a voluntary buyout program following Hurricane Sandy. ${ }^{6}$ What do we do with these defenseless territories?

WET+WILD! is an urban design proposal that builds on the issues that were brought about by Hurricane Sandy and addressed by the six Rebuild by Design teams. WET+WILD! catalogues and collects urban waste products to create a squishy landscape that is resourceful, recreational and resilient along New York City's 42nd Street. This soft landscape slows storm water runoff, manages excess rainwater, revives native ecologies and provides coastal defense. The Union of Concerned Scientists, an advocacy organization that conducts and communicates climate change related research, recently published a report that states "while today (in the United States) there about 90 communities that face 'chronic inundation,' that number could reach nearly 700 by the year 2100."7 In the scientists' most extreme sea level rise scenario, 60 percent of the East and Gulf Coast towns will be chronically inundated by 2100, including most of New York City. "On a globally averaged basis, sea level has risen about eight inches since 1880." ${ }^{8}$ For these reasons, WET+WILD! design approaches are a must- "Increased flooding is inevitable, and adaptation is now essential."

FROM WASTE PRODUCTS TO WASTE PRODUCTS: SOIL New York City is surrounded by ports on the Hudson, Hackensack and Passaic Rivers. Every year, 3 million cubic yards of silt are collected from these water bodies in an effort to facilitate the flow of boats. The majority of the material is sand and mud, with a lesser portion being clay, rock and glacial fill. In addition, an abundance of soil is excavated annually during the construction process of NYC's many building projects. Using a cut-and-fill landscape strategy, WET+WILD! proposes to distribute the re-usable portions of these earthen materials along 42nd Street to create an undulating topography that collects and choreographs the movement of water, promotes physical activity and allows for urban agricultural production. 
Figure 1: A Chinese child swims in Lake Tai, despite the toxic algae bloom that resulted from agricultural and industrial pollutants.

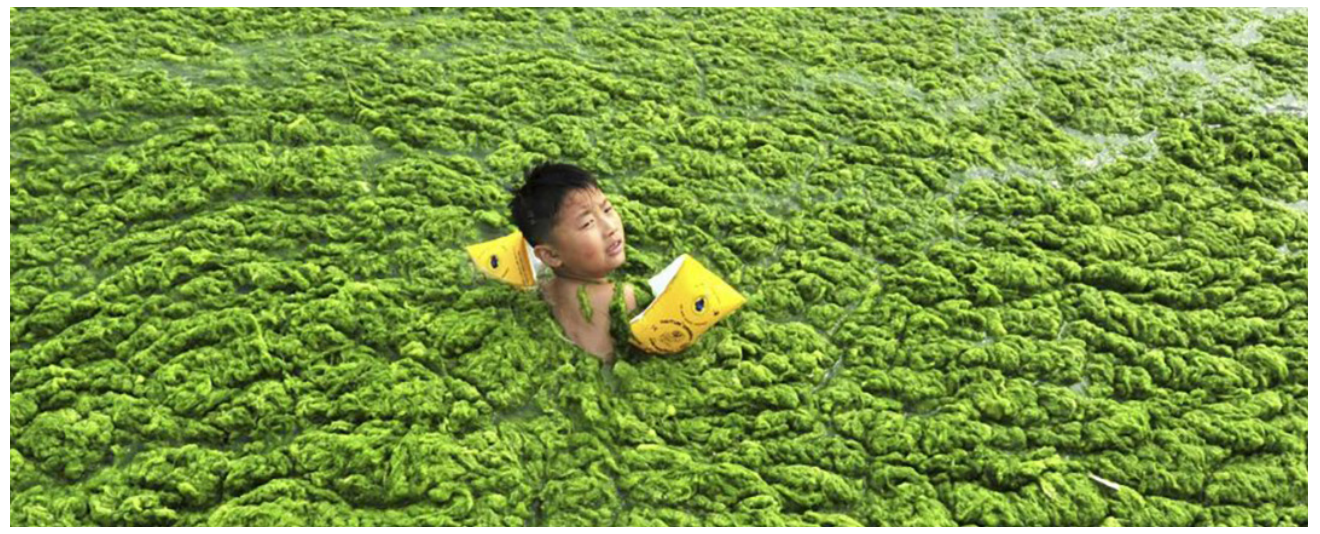

\section{FROM WASTE PRODUCTS TO WASTE PRODUCTS: WATER}

Every day, 13 million gallons of water are removed from New York City's 842 miles of subway tracks. 748 pumps located throughout the city's 309 pump stations direct this waste water into manholes which then empty into New York City's waterways. Additionally, abundant amounts of waste water enter New York City's soil system and river-ways in the wake of severe rain and snow storms. Simultaneously, impressive amounts of waste water are produced in the form of condensation from the HVAC systems of New York City's skyscrapers during the warm weather months. WET+WILD! proposes to collect and re-use this waste water along the length of 42 nd Street. Using gravity-fed purification processes that line the undulating artificial topography and phytoremediation techniques, brown water becomes blue water. These constructed remediation waterways provide a productive and pleasant landscape from river-to-river that purifies polluted water before returning it to the earth.

\section{FROM WASTE PRODUCTS TO WASTE PRODUCTS: COMPOST}

New York City residents dispose of 20,000 tons of autumn leaves and 100,000 Christmas trees per year. Additionally, 400,000 tons of food waste is produced each month. All of this matter is compostable. WET+WILD! proposes to further encourage composting and to make use of this material locally, both as a soil supplement and as a heat source. During the winter months, when the compost is abundant, it provides "Hot Spots" along 42nd Street. During the spring and summer months, when the demand for heat has diminished, the compost will be distributed throughout the WET+WILD! food forests, flowering meadows and plant plots. This resourceful urban landscape will help provide shelter, livelihoods, water, fuel and food to some of New York City's 8.5 million residents.

WET+WILD! provides a wondrous terrain that promotes an extensive array of human activities-From walking, running, biking, and playing to planting, growing, sharing and collaborating. This re-conceptualization of urban waste produces a dynamic landscape of flexible systems, services and resources to support and cultivate a more ecologically sensitive and resilient urban environment that is fertile and rich with the potential for production. This design approach creates pleasant urban spaces while addressing the Climate Resiliency Guidelines that were established in the spring of 2017 by the New York City Mayor's Office of Recovery and Resiliency.

\section{MEDIUM SCALE: LIQUID LANDSCAPES CREATE RECREATIONAL AND REMEDIATIVE SOCIAL SPACES}

Only $2.5 \%$ of the earth's water supply is potable and much of that is wasted, polluted and distributed unfairly. Since 1950 , the world population has nearly tripled, but water consumption has increased six fold. Low tech, self sufficient and affordable water collection systems have been around for centuries. These constructs condense, collect, cleanse and store potable water from the environment. Air wells, rain chains, step wells, chlorination pots and condensation collectors are all examples of scalable, modular and low-tech water systems that must be revisited and re-imagined.

\section{MUNICIPAL MANUFACTURING: PROVIDING PURIFICATION, PRODUCTION AND PLEASURE FOR SUZHOU}

The Chinese city of Suzhou is situated on the lower reaches of the Yangtze River, just west of Shanghai. Suzhou is geographically nestled at the intersection of several bodies of water which are crucial to China's livelihood. These include:

1) The Yangtze River

One of the most important rivers in the history, culture and economy of China. The Yangtze River flows through a wide array of ecosystems, provides an abundance of resources and acts as a major east/west transportation corridor in China.

\section{2) The Grand Canal}

This 1,100 mile long canal stretches from Beijing to Hangzhou and serves as the Eastern Route of the South North Water Transfer Project. In the past, the Grand Canal has acted as 


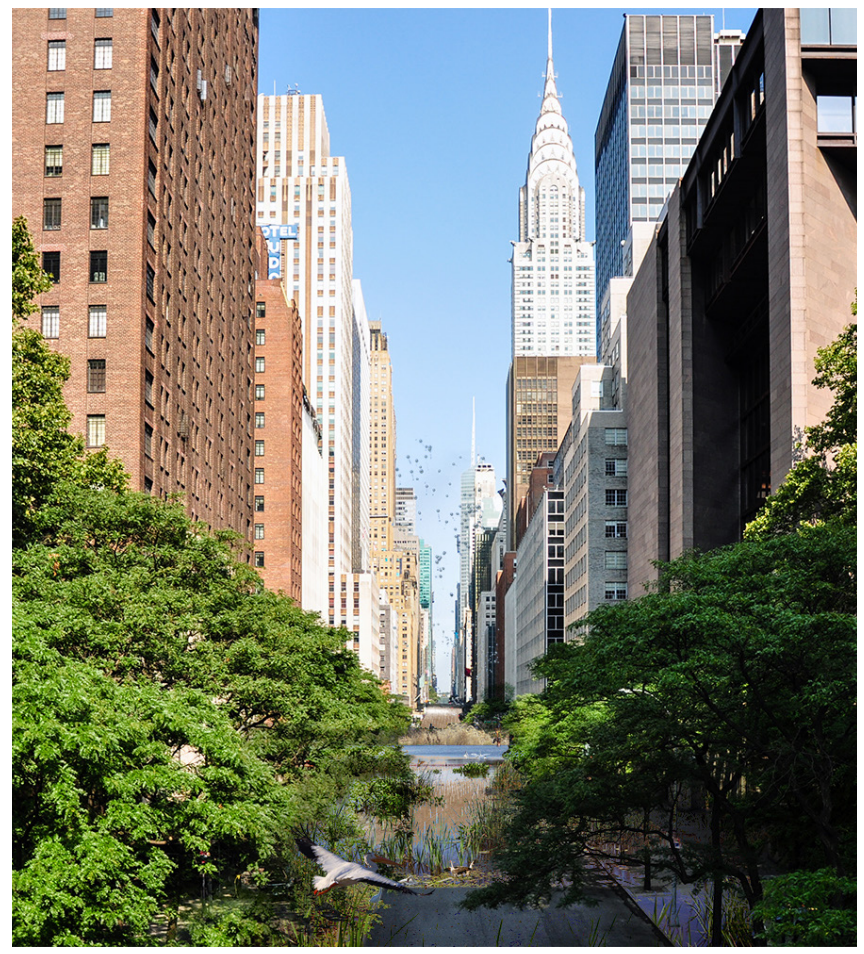

Figure 2: A view of the WET+WILD! design proposal, looking from the east end of NYC's 42nd Street to the west.

a major artery to support the exchange of goods, cultural practices and political ideas. Today it still operates as a major north/south transportation route.

\section{3) Lake Tai}

As the third largest lake in China, Lake Tai is linked to the Grand Canal and is the origin of a number of the smaller bodies of water in the area. In recent years, Lake Tai has been plagued by pollution as a result of rapid economic growth in the surrounding region. Lake Tai is also known for its productive fishing industry. Since the late 1970s, harvesting aquatic products such as fish and crabs has been invaluable to people living along the lake and has contributed significantly to the economy in the surrounding area. Lake Tai is home to over 30 species of fish, providing 10 percent of the fresh water fish in China.

Aquatic ecosystems "support more than 660 million jobs globally and are a significant source of protein", ${ }^{10}$ particularly for the Chinese populations that live along and around Lake Tai. The effects of climate change and poor industrial practices are doing incredible damage to our world's aquatic ecosystems. In 2014, the World Wildlife Federation's Living Planet Report revealed that the planet's freshwater species have declined by a startling 76 percent, with the sharpest population decrease taking place in South America and Asia-Pacific. ${ }^{11}$ The primary threats to freshwater species are habitat loss, water body fragmentation, pollution and invasive species. ${ }^{12}$ Additionally "infrastructure development, intensive agricultural expansion, urbanization and coastal development are increasing pressure on aquatic ecosystems. The situation is most severe around Europe, the east coast of the United States, east China and Southeast Asia. These are also primary fishing grounds. ${ }^{13}$ Lake Tai also serves as a major fresh water resource, supplying four major cities: Shanghai, Suzhou, Wuxi and Huzhou. Maintaining the precious natural resource of Lake Tai-a body of water that provides food and economic stability for the region-is crucial.

\section{A Closer Look at Lake Tai}

In the 1970's pollution affected Lake Tai, impacting the 36 million people that are dependent on the lake for drinking water and food production. Despite efforts to clean the lake in the late 1990s, the level of pollution rapidly increased. A major source of pollution, particularly in the eastern region of the lake, is the intensive agricultural production which has injected nitrates and phosphates into the water system causing eutrophication and "dead zones" to occur. The great increase of phytoplankton in Lake Tai has had negative environmental effects, including the depletion of oxygen content in the water, otherwise known as hypoxia. This induces reductions in specific fish and other ecological populations, which begins the process of a downward spiral.

The consequences of the region's pollution problem have been drastic. In the summer 2007 the city of Wuxi was cut off from drinking water for more than a week. Due to the demand, bottled water prices rose from $\$ 1$ a bottle to $\$ 6$ a bottle, putting a major financial strain on most Chinese households. During the same period, people were taking showers with bottled water due to the high concentration of blue-green algae flowing through their faucets.

\section{Closer Look at the Suzhou New District Site}

A closer analysis of Suzhou New District's urban context reveals several interesting issues related to the regional water quality and food production crisis. A series of analytical layers were mapped to reveal that the area surrounding the specific site is severely lacking:

\section{1) Waste Water Treatment Facilities}

\section{2) Transfer Stations}

\section{3) Urban Agriculture Plots}

\section{4) Grocery Stores}

Additionally, the site is bordered by three primary types of programs:

\section{1) Residential Housing}

\section{2) Industrial Fabric}

\section{3) Public Services}




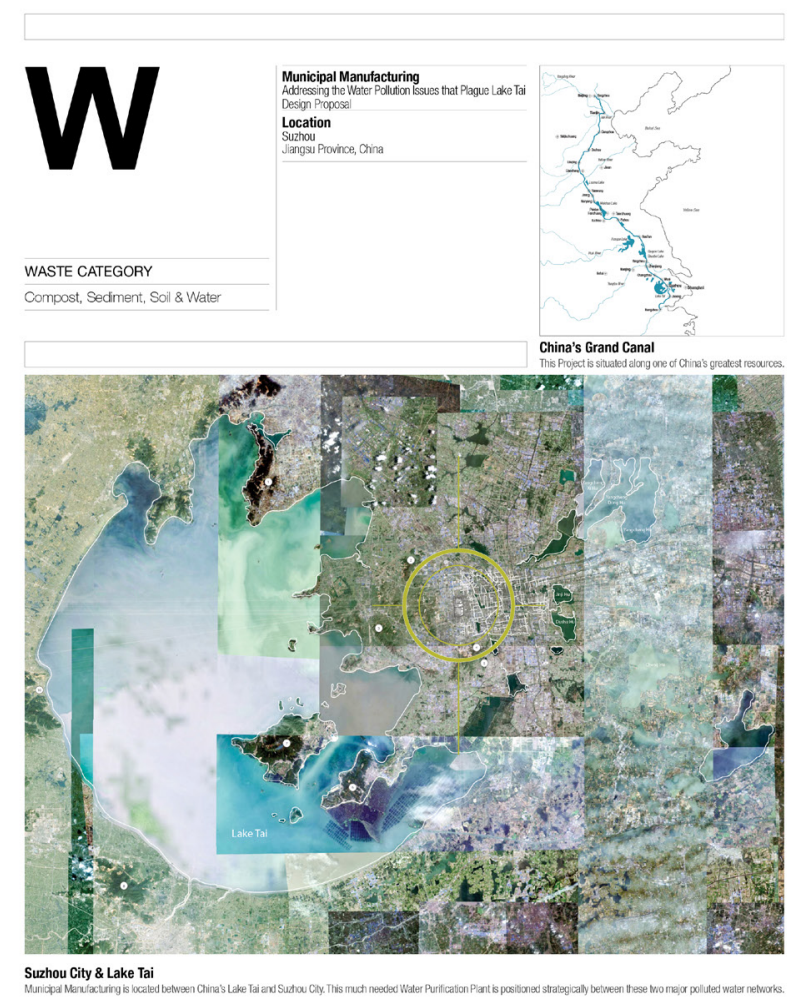

Figure 3: Summary of the Municipal Manufacturing design proposal.

With this information mapped and these deficiencies in mind the question becomes how might one design a pollution solution and provide the lacking amenities outlined above on the residential, industrial and municipal scales? MUNICIPAL MANUFACTURING aims to create a resourceful retreat in Suzhou that provides water purification, food production and public pleasure. The design operates on a variety of scales, ranging from the individual, to the household, to the neighborhood, to the community, to the city and to the region. These scales are accommodated through a number of interventions that address the nutritional, physical and economical needs of the local people. The design is implemented in three major phases:

\section{PHASE (1) PURIFICATION}

The first step of phase one entails laying out water purification pools and infrastructure. These devices provide opportunities to responsibly tap into ground aquifers, collect rain fall, intake canal water and store $\mathrm{H} 2 \mathrm{O}$ transported from afar. Pools are classified according to water types and their degree of contamination-blue, green, grey, brown and black water. The water content undergoes a natural filtration process and is eventually available to be used as a source for crop irrigation and ultimately drinking water.

Along with providing clean water, moments within this infrastructure encourage the growth of algae and phytoplankton.

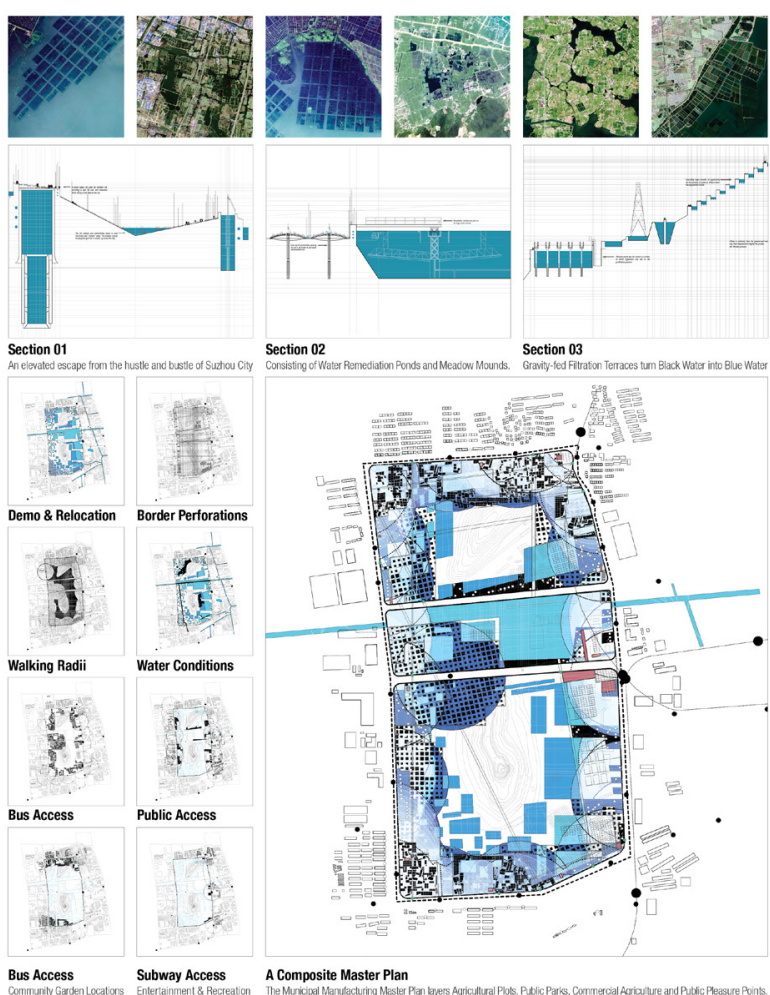

When farmed, these organisms provide an alternative source of energy in the form of biofuel. MUNICIPAL MANUFACTURING proposes to transplant this natural annoyance from Lake Tai where it devastates to the new site where, when under careful surveillance, it cultivates. "Algae are the primary producers of organic matter, the base of the food chain, and the principal source of oxygen for all aquatic life."14

\section{PHASE (2) PRODUCTION}

Initially, two main constituents related to the site are outlined and then coupled with a form of productive urban development according to the scope the constituent serves:

1) Residential Fabric (S scale) > Community Agricultural Gardens

2) Bus Stops (M scale) > Commercial Agricultural Gardens

The seeds of these community and commercial agricultural gardens are first planted at points within the site where the highest frequency of traffic takes place. Each garden zone contains at least one market space for the collecting, selling and redistributing of goods.

For the residential inhabitants, the community gardens provide the opportunity for residents to have an outdoor space of their own in an effort to supplement the inadequate existing residential conditions. Community garden zones are subdivided amongst residents, at which point the land is used for the individual's preferred purpose. 

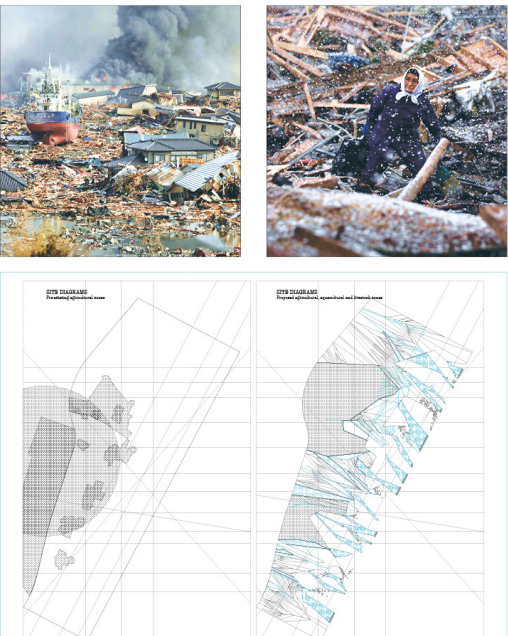

MAP: Agriculture \& Aquaculture Existing (Left) and Proposed (Right)

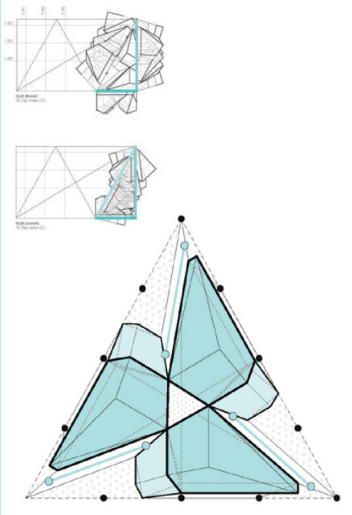

The Irreducible Unit

Two Residential Units were created: A Small Unit (1-2 People) and a Large Unit (3-4 People).

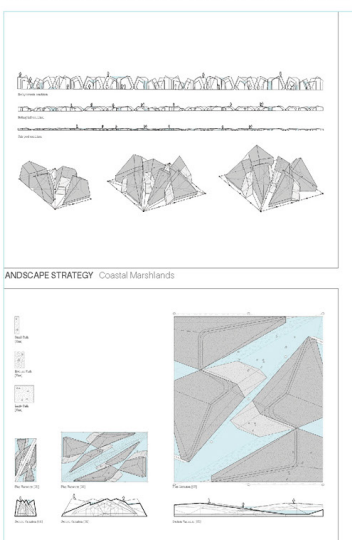

Eliminating the Sea Wall

To favor the creation of a networked range of artificial landforms and man-made water bodies.

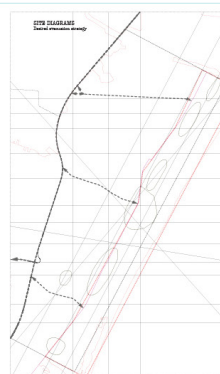

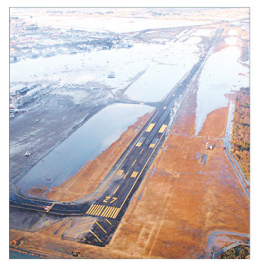
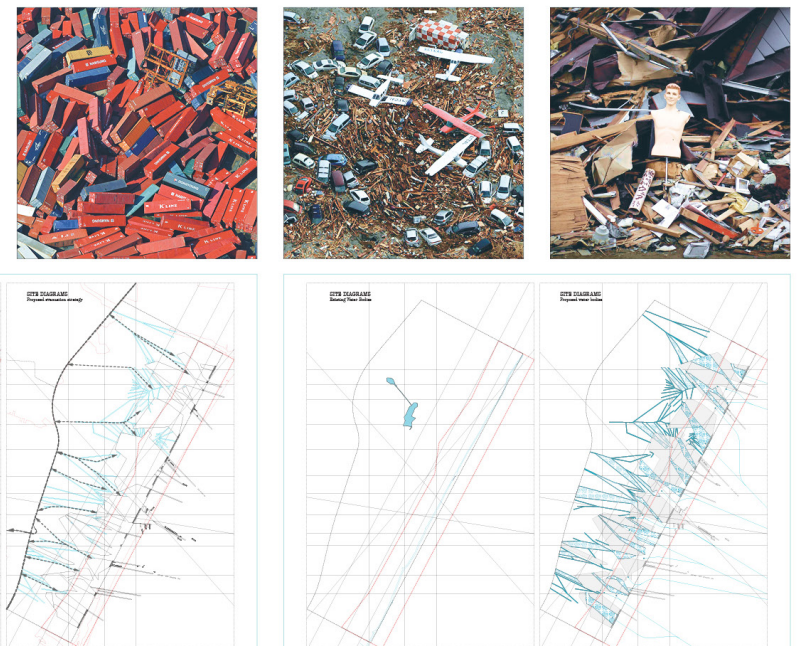

gaspases

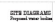

\section{MAP: Water Bodies}

Existing (Left) and Proposed (Right)

Existing (Left) and Proposed (Right)

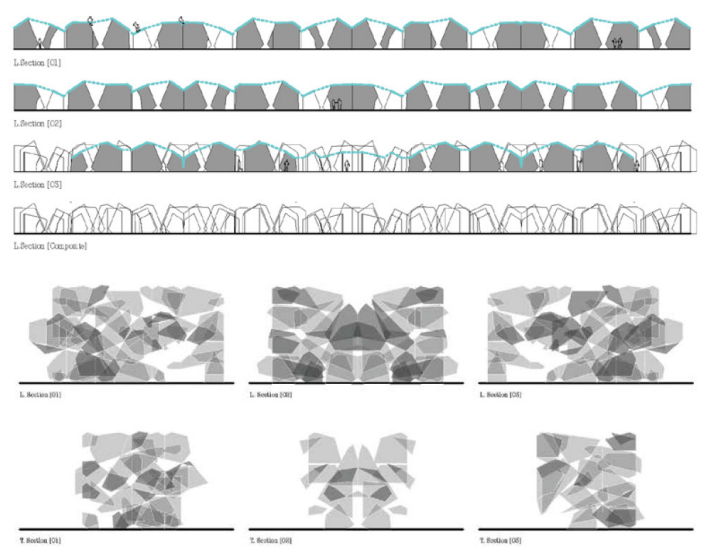

Irreducible Unit Aggregation

The Units were aggregated to create a variety of Roofscape experiences and Spatial Collisions.
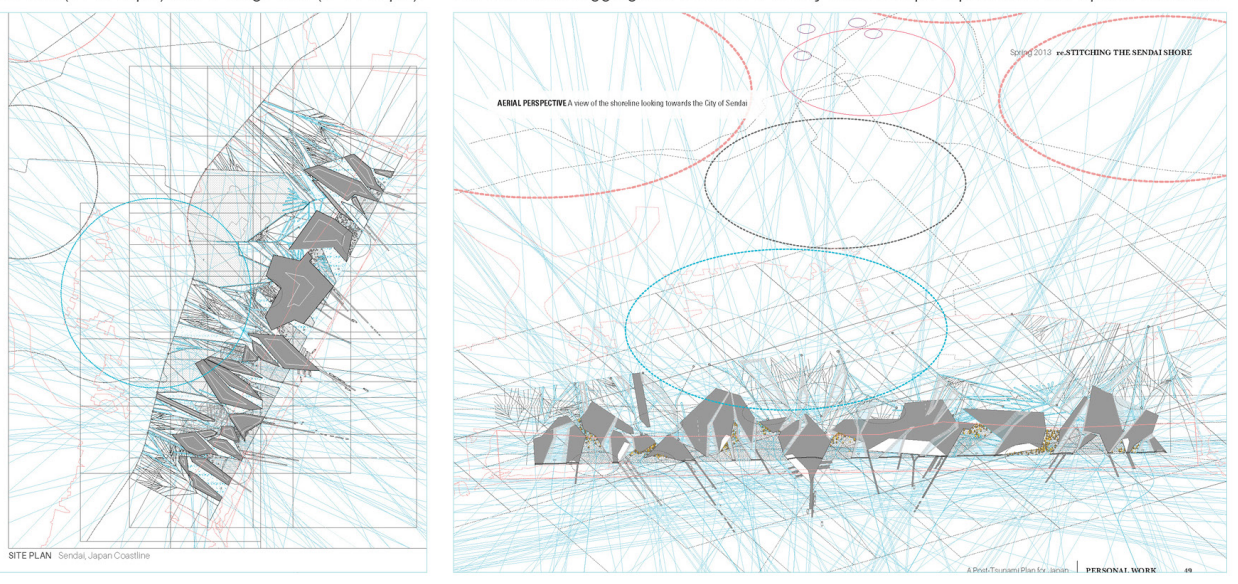

Productive Landscapes

These Productive Forms create multi-functional landscapes that serve the entire local population. 
The commercial gardens are closely linked to the existing bus stops with the intention that these spaces will provide a point of production and purchase on a larger, more public scale. Residents of the greater community may hop on and off the bus to pick up ingredients for dinner on their way to and/or from work. These gardens also operate on a regional scale, acting as a point of agricultural production for the surrounding communities. "Agriculture accounts for 92 percent of the global water footprint."15 On average, "every calorie we eat requires a liter of water to produce."16 MUNICIPAL MANUFACTURING aims to encourage sustainable food production practices by using recycled water from within the designed system to grow food locally, on multiple scales.

\section{PHASE (3) PLEASURE}

Next, two more constituents are defined and coupled with larger scale public programs:

\section{3) Civic Fabric (L scale) > Public Parks}

4) Subway Stops (XL scale) > Recreational Parks

Like the previous phase, these points are first implemented within the most highly trafficked zones of the site.

The public parks associated with the civic fabric operate like conventional public green spaces, with park benches, grassy meadows, trees and small water ponds. These parks provide moments for the population, both permanent and transient, to have lunch and play in the park.

The recreational parks serve the greater population, acting as a destination point accessed by the existing subway system. These larger plots of pools and land serve the (FUN)ction of providing pure pleasure for the public in the form of water and amusement parks. The recreational parks make Suzhou a major transportation and entertainment node, bridging the gaps between Lake Tai in the west and Shanghai in the east.

\section{LARGE SCALE: LETTING THE WATER IN TO KEEP THE DEVASTATION OUT}

On Friday, March 11th, 2011 a devastating tsunami bulldozed Japan's Tōhoku and Sanriku coasts, leveling most everything within its path. In total, the catastrophe took 15,781 lives, left 4,086 people missing and created 23 million tons of debris. As a result, architects, landscape architects, urban designers and engineers have been challenged to rethink the way we consider strength, rigidity and resiliency in large-scale, coastal design interventions. In the wake of the 2011 Tōhoku earthquake and tsunami, Japanese officials began to discuss and debate the possibility of turning the damaged land along the shore of Sendai city into a public park that anticipates future risks but also affords optimistic urban experiences. Of interest were design ideas that address issues of safety, land use, energy, agriculture, recreation and memory. Additionally, Sendai officials were interested in addressing the loss of the Sewage Treatment Plant, the Igune Villages and the Seaside Park Adventure Field as well as the degradation of the Arahama Elementary School and the GAMO tidal flats.

In response to these post-tsunami impulses, re.Stitching the Sendai Shoreline explores the possibility of eliminating the construction of a barrier-making seawall in favor of creating a networked range of artificial landforms and man-made water bodies to create a productive, multifunctional, resilient landscape that is accessible to the entire local population in a variety of ways. Learning from the pros and cons, successes and failures of coastal reclamation projects in southeast Asia like the impressive expansion of Singapore - a country that "since 1965, dilated from 224.5 to 276.5 square miles ${ }^{17}$ this project capitalizes on the softness, scalability and malleability of earthen matter.

First, a cut-and-fill process is used to transform the landscape by extracting and redistributing earthen matter. This process results in a series of mounds and water retention pools that border the coastline. This man-made, porous boundary acts as a "natural" seawall that collects incoming water, provides protection and creates elevated evacuation points that are planted with disaster-prevention forests. Additionally, the retention pools accommodate multi-trophic aquaculture activities to foster food production and remediation techniques desalinate the land and water on site. This poly-functional infrastructure simultaneously supports aquaculture economies, reuses fish waste and treats grey water. Approximately "95 percent of our planet's water is salt water. Almost all of the remaining fresh water is locked up in glaciers and ice caps, or in aquifers deep under the surface ${ }^{\prime 18}$ and only a fraction of one percent of fresh water is renewed each year by natural hydrological cycles. For this reason, environmentally sensitive design strategies that collect and cleanse water are necessary to ensure more feasible future scenarios.

The mounds provide agricultural terraces and recreational spaces on the surface with inhabitable interior space for food storage and tsunami shelters. Nutrient rich fish-waste fertilizers are used to nourish the newly planted crops. Second, a series of canals are excavated on the Sendai City side of the natural sea wall. These man-made waterways transport people, products and water transversely across the site, from sea to city. Third, agriculture and livestock plots are laid out between the canals to reintroduce the productive landscape that once flourished along Sendai's shoreline. Fourth, the entire water's edge is interlaced with port and recreational activities to revive the coastline with semi-permanent forms of habitation. Inhabitable mounds dot the shoreline, acting as bunkers to provide secure shelters for the people and products related to the seaside activities. This network of water canals and the newly raised Shiogama-Watari Prefecture Road create a fluid connection between the activated waterfront and the heart of Sendai city. 


\section{RE.STITCHING THE SENDAI SHORELINE: BUILDING STRATEGY}

The irreducible habitation unit is a scalable, crystalline module that can be aggregated in various ways to range in form and scale-from smaller living units to larger scaled urban agglomerations. These crystalline structures enable and encourage maximum interaction between inhabitants. The building forms are primarily located on the lee side of the mounds to ensure maximum protection from incoming sea water and other elements related to inevitable natural disasters. As water infiltration erodes the earthen mounds and sediment is redeposited over time, the crystalline structures are concealed and revealed along the waterfront. The result is an ever-evolving, fortified urban landscape that lines the Sendai shore and perpetually readjusts according to the dynamic natural elements-wind, water, sand and snow.

re.Stitching the Sendai Shoreline aligns with the city's existing desire to be a sustainable city that protects biodiversity and its natural environment. For several years, Sendai has been working to develop green purchasing practices. The city's municipal institutions ensure that more than 90 percent of their purchases are green products. re.Stitching the Sendai Shoreline provides additional opportunities for the city to "go-green" and consume local, whether it's water, food or fun.

\section{LOOKING FORWARD}

The well-being of humankind is dependent on the earth's native resources like water, land, fish, game and the natural processes that ecosystems undergo, like pollination, nutrient cycling and erosion control. "More than 60 percent of the vital services provided by nature are in global decline because of over-exploitation."19 It's no secret that issues of food, water and energy security are undoubtedly interconnected and affect all of us. "Today, almost a billion people suffer from hunger, 768 million live without a safe, clean water supply and 1.4 billion lack access to a reliable electricity supply." ${ }^{20}$ Projections made by the World Wildlife Federation suggest that we need 1.5 Earths to meet the demands that we currently put on mother nature. "With another 2.4 billion people to be added to the human population by 2050, the challenge of providing everyone with the food, water and energy they need is already a daunting prospect."21 As designers, it's our responsibility to place ecosystems and the management of natural resources at the center of our design approaches, regardless of the project's scale and context. Doing so will bring us one step closer to decelerating the effects of climate change and will provide economic and social benefits.

The projects presented in Fluid Futures tackle the challenges presented by climate change head on in three distinct contexts. Though the physical and cultural landscapes differ, each of these projects works to restore damaged ecosystems and halt the loss of natural habitats. Simultaneously, these design ideas promote resourceful ways of thinking and making by transforming waste into wonder and managing resources sustainably. Additionally,
WET + WILD!, MUNICIPAL MANUFACTURING and re.Stitching the Sendai Shoreline encourage us to be more conscientious consumers by promoting low-footprint lifestyles that rely on sustainable energy sources and local food production. Through this lens, the future is wet, and full of resilient ecologies, robust economies and natural resources.

\section{ENDNOTES}

1 Arjen Y. Hoekstra and Mesfin M. Mekonnen, "The Water Footprint of Humanity", Proceedings of the National Academy of Sciences 109(9), (2012), 3232-3237.

22030 Water Resources Group, “Charting Our Water Future: Economic Frameworks to Inform Decision Making," 2030 Water Resources Group (Washington, DC: 2009).

3 UNDESA, “World Urbanization Prospects - The 2011 Revision," United Nations Department of Economic and Social Affairs (New York: United Nations, 2012).

4 Ibid.

5 Henk Ovink, "Regional Design Thinking," in Wet Matter, eds. Pierre Bélanger and Jennifer Sigler (Cambridge: Harvard GSD, 2014), 160.

6 Robert Freudenberg, Ellis Calvin, Laura Tolkoff and Dare Brawley, "Buy-in for Buyouts: The Case for Managed Retreat from Flood Zones," Lincoln Institute of Land Policy (Cambridge, 2016)

7 Katharine Schwab, "Water Will Be This Century's Great Urban Design Challenge," Co.Design, July 18, 2017.

8 John A. Church and Neil J. White, "Sea Level Rise from the Late 19th to the Early 21st Century," in Surveys in Geophysics 32 (2011): 585-602.

9 Erika Spanger-Siegfried, Kristina Dahl, Astrid Caldas, Shana Udvardy, Rachel Cleetus, Pamela Worth and Nicole Hernandez Hammer, "When Rising Seas Hit Home: Hard Choices Ahead for Hundreds of US Coastal Communities," Union of Concerned Scientists (2017), 3.

10 The World Wildlife Federation, Living Planet Report 2014: Species and Spaces, People and Places (Gland, Switzerland: WWF, 2014), 10.

11 Ibid., 12

12 Ben Collen, Felix Whitton, Ellie Dyer, Jonathan E.M. Baillie, Neil Cumberlidge, William R.T. Darwall, Caroline Pollock, Nadia I.Richman, Anne-Marie Souldby and Monika Böhm, "Global Patterns of Freshwater Species Diversity, Threat and Endemism", Global Ecology and Biogeography 23, (2014), 40-51.

13 Ibid., No.10, 88

14 Catherine Seavitt Nordenson, "The Bottom of the Bay, Or How to Know the Seaweeds," in Wet Matter, eds. Pierre Bélanger and Jennifer Sigler (Cambridge: Harvard GSD, 2014), 7.

15 Ibid., No.10, 7.

16 Ibid., No.10, 92

17 Joshua Comaroff, "Singapore and the New State of Risk," in Wet Matter, eds. Pierre Bélanger and Jennifer Sigler (Cambridge: Harvard GSD, 2014), 142.

18 Sandra Postel, Gretchen Daily and Paul Ehrlich, "Human Appropriation of Renewable Fresh Water", Science 217, no.5250 (1996), 785-788.

19 MEA, "Ecosystems and Human Well-being: Synthesis," Millennium Ecosystem Assessment (Washington, DC: Island Press, 2005).

20 Ibid., No.10, 11

21 Ibid., No.10, 86 